\title{
The Diversification of Air Temperature Trends in Poland (1981-2010)
}

\author{
Agnieszka Ziernicka-Wojtaszek*, Joanna Krużel \\ Department of Ecology, Climatology and Air Protection, University of Agriculture \\ Mickiewicza 24/28, 30-059 Kraków, Poland
}

Received: 18 January 2016

Accepted: 12 April 2016

\begin{abstract}
The aim of this study is to answer questions such as: What is the pace of warming? How diversified is it in particular months? How is it spatially diversified in Poland in the 1981-2010 30-year period constituting the new, normal climate? The study was based on materials concerning monthly mean air temperature values from the above-mentioned period from 53 weather stations belonging to the network of the Institute of Meteorology and Water Management spread evenly across Poland. It was stated that warming in Poland in the $1981-2010$ period, amounting to $0.33^{\circ} \mathrm{C} / \mathrm{decade}$, resulted mainly from a spring and summer temperature increase of $\alpha=0.05$. Temperature increases occurred at the greatest pace in July (0.81) and April (0.73). The pace is slightly slower in June $\left(0.57^{\circ} \mathrm{C}\right)$, and August $\left(0.48^{\circ} \mathrm{C} /\right.$ decade). A high trend for February $\left(0.85^{\circ} \mathrm{C} /\right.$ decade $)$ is not statistically significant. Trend values in October and December of $0.2^{\circ} \mathrm{C} /$ decade are negative but statistically insignificant. The regional differentiation of statistically significant temperature trends in Poland is as follows: in April the greatest increase in temperature is visible in mid-western Poland, with the lowest values in: Zielona Góra 0.96, Gorzów Wielkopolski 0.88, Bielsko Biała 0.85, and Poznań $0.84^{\circ} \mathrm{C} /$ decade. In June, there is a decrease of trends, from the highest values in southwestern Poland to the lowest in northeastern Poland: Zielona Góra 0.79, Poznań 0.74, Kalisz 0.61, Płock 0.57, and Ostrołęka $0.36^{\circ} \mathrm{C} /$ decade. In July there is a decrease of trend values from east to west: Suwałki 1.08, Warsaw 0.97, Poznań 0.89, Legnica 0.71, Zielona Góra 0.69 , and Szczecin $0.57^{\circ} \mathrm{C} /$ decade. In July and August a decrease in trend values can be observed from east to west: Zamość 0.71 , Warsaw 0.49 , and Szczecin $0.27^{\circ} \mathrm{C} /$ decade.
\end{abstract}

Keywords: temperature, trend changes, Poland, global warming

\section{Introduction}

The pace of global warming has been increasing significantly. According to the Fourth IPCC Assessment Report for the last 150 years, it amounted to just $0.045^{\circ} \mathrm{C} /$ decade, for the last hundred years $0.074^{\circ} \mathrm{C} /$ decade, and for the last 50 years $0.128^{\circ} \mathrm{C} /$ decade - only to increase

*e-mail: aziernik@poczta.fm further in the last 25 years to $0.177^{\circ} \mathrm{C} /$ decade [1]. The data concerning the pace of global warming, published in the Fifth IPCC Assessment Report for the years 19792012 , indicate still higher values. The values amount to $0.25^{\circ} \mathrm{C} /$ decade, according to such authors as Jones et al. [2] and Rohde et al. [3], or to $0.27^{\circ} \mathrm{C} /$ decade, according to such authors as Hansen et al. [4] and Lawrimore et al. [5]. The juxtaposition of annual global air temperature values for the particular decades of the 1931-2010 period, 
after rounding them off to $0.1^{\circ} \mathrm{C}$, demonstrate temperature values of the order of $13.9^{\circ} \mathrm{C}$ in the first five decades. Meanwhile, in the decades 1981-1990, 1991-2000, and 2001-2010 the values were higher and higher, amounting to $14.1,13.3$, and $14.5^{\circ} \mathrm{C}$, respectively [6].

Temperature trend values for Poland are slightly higher than global ones, with a marked increase in the pace of warming. Thus Żmudzka [7] for 1951-2000 and Michalska [8] for the 1951-2005 period come up with values of $0.2^{\circ} \mathrm{C} /$ decade, Wójcik and Miętus [9] for the $1951-2010$ period with $0.22^{\circ} \mathrm{C}$, and Krużel [10] for the $1971-2010$ period with a still higher value of $0.33^{\circ} \mathrm{C} /$ decade. In Poland, significant warming has been observed from the 1980s onwards. Kożuchowski and Żmudzka [11], while presenting graphically the course of annual mean temperature values in Poland in 1951-2000 as a trend curve, emphasize the significant temperature increase from the 1980s onwards. Żmudzka [12] divides the abovementioned period into decades: 1951-1960, 1961-1970, and 1971-1980 with temperature values of 7.7, 7.5, and $7.7^{\circ} \mathrm{C}$, respectively, as well as two subsequent warmer ones with temperatures of 8.0 and $8.3^{\circ} \mathrm{C}$. Wójcik and Miętus [9] cite similar values for the subsequent decades of the 1951-2010 period: 7.6, 7.4, 7.6, 8.0, 8.3, and $8.6^{\circ} \mathrm{C}$.

As for the seasonal diversification of increasing temperature trends in Europe and Poland, the opinions of authors publishing their research results at the turn of the $21^{\text {st }}$ century can be summarized by saying that the warming manifests itself as the existence of warmer and warmer winters, whereas in summer months the temperature trend is zero or even negative [13-16]. Meanwhile, the authors who published their research results a few years or a decade later draw our attention to the two last decades of the $20^{\text {th }}$ century, and the first years (or the first decade) of the $21^{\text {st }}$ century, when warming is observed not only in the winter and spring months, but also in summer [17-19].

Work on this paper was started under the outlined circumstances. Its aim was to characterize air temperature trends in particular months and years in the range of territorial mean values for Poland. For the months in which trend values proved statistically significant, a spatial diversification of trends was presented. The period under research was 1981-2010. It is a period from which onwards there has been a significant increase in temperature - both on a global scale and in Poland. Moreover, the period is, according to World Meteorological Organization recommendations, a new climate normal, which substituted the 1971-2000 one (valid until recently).

\section{Material and Methodology}

The material used in this study was meteorological data concerning monthly air temperature values, from 53 Institute of Meteorology and Water Management weather stations placed evenly across Poland, for the 1981-2010 period. The weather stations included: Białystok, Biała Podlaska, Chojnice, Częstochowa, Elbląg, Gorzów Wielkopolski, Jelenia Góra, Kalisz, Katowice, Kętrzyn,
Kielce, Kłodzko, Koło, Koszalin, Kraków, Legnica, Lesko, Leszno, Lębork, Lublin, Łódź, Mława, Nowy Sącz, Olsztyn, Opole, Ostrołęka, Piła, Płock, Poznań, Przemyśl, Puławy, Racibórz, Resko, Rzeszów, Sandomierz, Siedlce, Słubice, Sulejów, Suwałki, Szczecin, Szczecinek, Świnoujście, Tarnów, Terespol, Toruń, Ustka, Warszawa, Wieluń, Włodawa, Wrocław, Zamość, Zgorzelec, and Zielona Góra. Mountain, and, above all, high mountain areas are poorly represented in the study because of a lack of weather stations in them. The materials were checked and, in a few cases, completed using the method of finite differences. Linear air temperature trends for territorial mean values from the 53 weather stations were calculated for the particular months and years in the 30-year research period. For the months with significant trend values at the $\alpha=0.05$ level, the trends were calculated for particular weather stations, and their diversification in Poland was illustrated. The isolines were drawn using Surfer 7 and the kriging method. The results were compared with those of other researchers, which usually concerned older and longer periods.

\section{Results and Discussion}

Warming in Poland in the 1981-2010 period, amounting annually to 0.33 a decade, is statistically significant, and results mainly from an increase in spring and summer temperatures (Table 1). The highest statistically significant temperature increase is in July, and amounts to $0.81^{\circ} \mathrm{C} /$ decade and in April $0.73^{\circ} \mathrm{C} /$ decade, but also in June at $0.57^{\circ} \mathrm{C} /$ decade, and August at $0.48^{\circ} \mathrm{C} /$ decade. Quite high trend values are also seen in February and November at 0.85 and $0.69^{\circ} \mathrm{C} /$ decade, respectively. They are not, however, statistically significant. Slight statistically insignificant trends are seen in January, March, and May. Their values are: $0.02,0.05$, and 0.03 , respectively. The slightly higher September values amount to $0.14^{\circ} \mathrm{C} /$ decade. The October and December trends are negative and amount to 0.19 and $0.20^{\circ} \mathrm{C} /$ decade, but are statistically insignificant (Table 1).

If we look into the regional diversification of the statistically significant air temperature trends, we can see that the highest April values appeared in southwestern

Table 1. Territorial mean air temperature trend values in Poland in 1981-2010.

\begin{tabular}{|c|c|c|c|}
\hline Month & Gradient ${ }^{\circ} \mathrm{C} /$ decade & Month & Gradient ${ }^{\circ} \mathrm{C} /$ decade \\
\hline January & 0.02 & July & $\mathbf{0 . 8 1}$ \\
\hline February & 0.85 & August & $\mathbf{0 . 4 8}$ \\
\hline March & 0.05 & September & 0.14 \\
\hline April & $\mathbf{0 . 7 3}$ & October & -0.19 \\
\hline May & 0.03 & November & 0.69 \\
\hline June & $\mathbf{0 . 5 7}$ & December & -0.20 \\
\hline
\end{tabular}

Statistically significant values $(\alpha=0.05)$ are in bold 


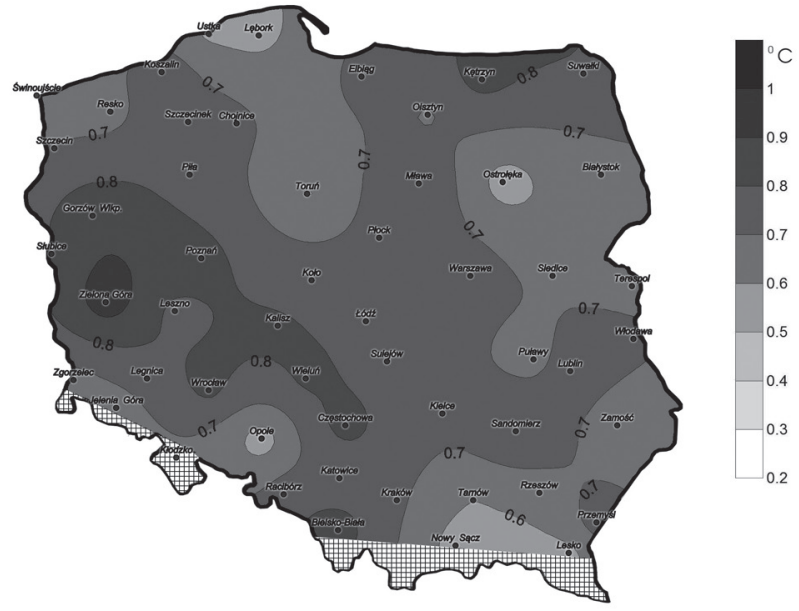

Fig. 1. Regional differentiation of air temperature trends in Poland, 1981-2010 $\left({ }^{\circ} \mathrm{C} /\right.$ decade $)$ for April.

Poland, namely in: Zielona Góra 0.96, Gorzów Wielkopolski 0.88, Bielsko Biała 0.85, and Poznań $0.84^{\circ} \mathrm{C} /$ decade. Trend values decreased toward the east, being lowest in Białystok 0.66, Terespol 0.67, and Zamość $0.62^{\circ} \mathrm{C} /$ decade (Fig. 1). A similar diversification is seen in another month, June, which is characterized by a significant increasing trend. In this case, trend values decrease from the southwest to the northeast, amounting, for example, to: Zielona Góra 0.79, Poznań 0.74, Częstochowa 0.75, Warsaw 0.67, Lublin 0.58, Włodawa 0.49 , and Białystok $0.35^{\circ} \mathrm{C} /$ decade (Fig. 2).

The spatial differentiation of air temperature trends in Poland in July looks somewhat different. The lowest trend values are in western Poland. Their values are: Szczecin 0.57 , Świnoujscie 0.59 , and Stubice $0.66^{\circ} \mathrm{C} /$ decade. Trend values increase toward the west, and amount, for example, to: Zielona Góra 0.69, Poznań 0.89, and Warsaw $0.97^{\circ} \mathrm{C} /$ decade. Near the eastern border of Poland they are 1.02 and $1.08^{\circ} \mathrm{C} /$ decade in Lublin, and Suwałki, respectively (Fig. 3).A similar increase in trend values (from

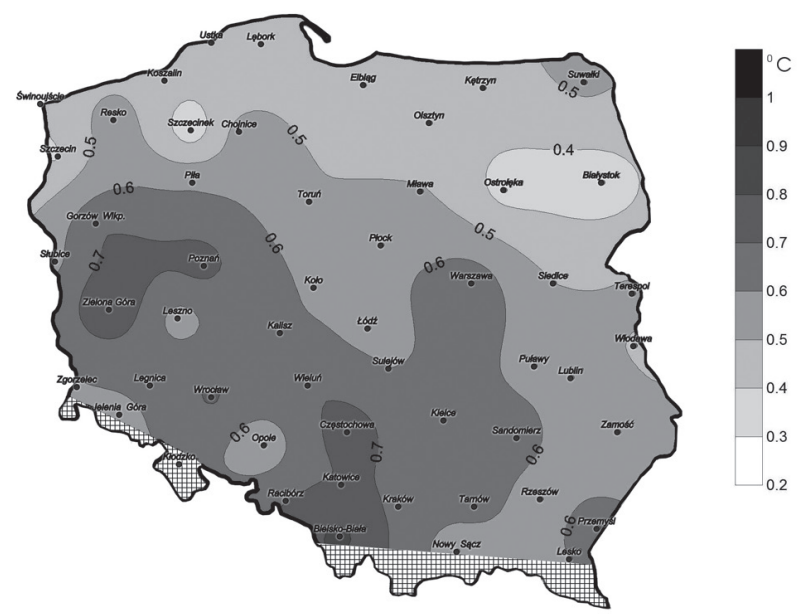

Fig. 2. Regional differentiation of air temperature trends in Poland, 1981-2010 $\left({ }^{\circ} \mathrm{C} /\right.$ decade $)$ for June.

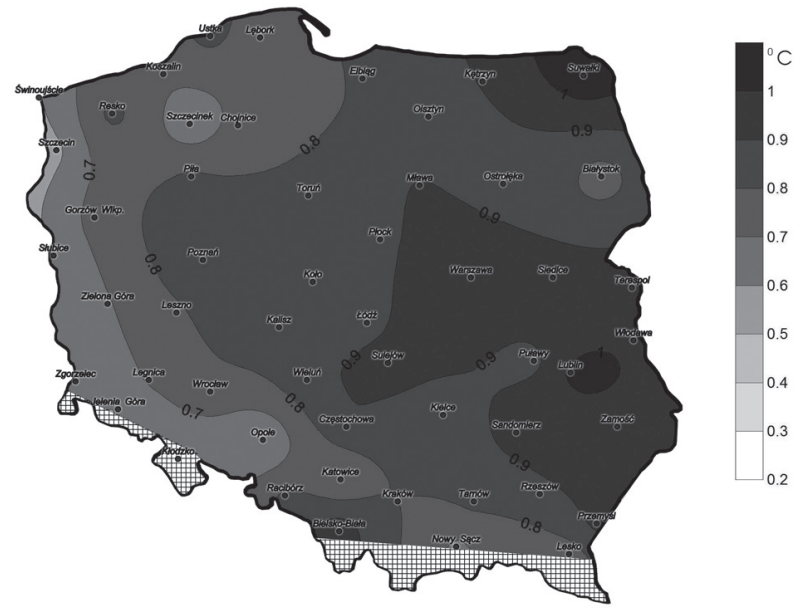

Fig. 3. Regional differentiation of air temperature trends in Poland, 1981-2010 $\left({ }^{\circ} \mathrm{C} / \mathrm{decade}\right)$ for July.

west to east) is visible in August. The values increase from 0.27 in Szczecin, to 0.49 in Warsaw, and are highest in Zamość at $0.71^{\circ} \mathrm{C} /$ decade (Fig. 4). The noteworthy months, with high, although statistically insignificant, positive trend values, are February at 0.85 and November at $0.69^{\circ} \mathrm{C} /$ decade.

A comparison of our research results with those of other authors is difficult, first and foremost due to our dealing with different research periods in order to determine air temperature trends using different thermal indicators that characterize economic or vegetation periods, and also due to the large number of regional and local studies. Both types of studies: the ones dealing with thermal differentiation in periods of instrumental observations (e.g., 1792-1995 for Kraków [19]), and the seldom seen studies of the most recent periods of 1981-2010 for Bydgoszcz [20], or 1971-2009 with a forecast for 2030-50 [21].

Most studies cover research periods from the 1980s or the above-mentioned ones, to the most recent times possible $[8,9,11,22,23]$. According to Okoniewska [24],

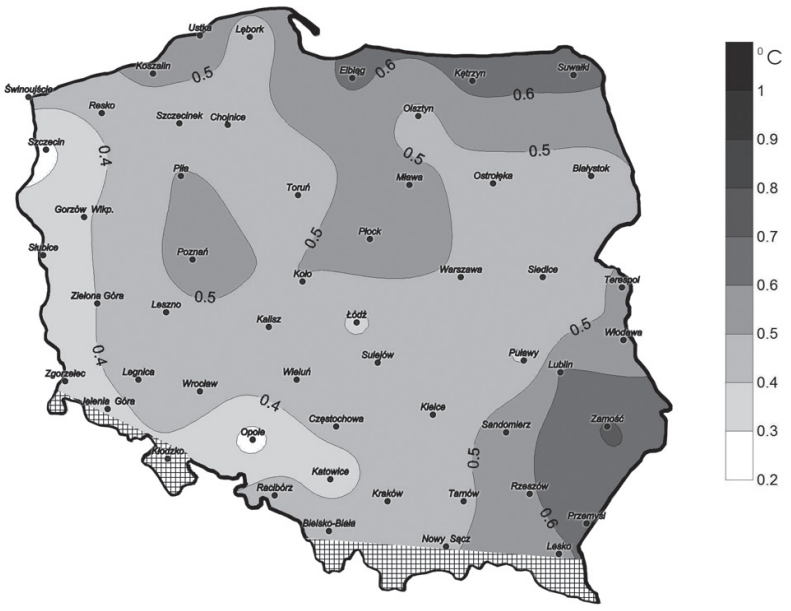

Fig. 4. Regional differentiation of air temperature trends in Poland, 1981-2010 $\left({ }^{\circ} \mathrm{C} /\right.$ decade $)$ for August. 
the January temperature trend for Gdynia for 1931-93 was $0.403^{\circ} \mathrm{C} /$ decade, while for Warsaw (1901-98) and for Kraków (1901-2000) it was 0.089 , and $0.129^{\circ} \mathrm{C} /$ decade. Thus, according to the research carried out, the trend value of 0.02 is statistically insignificant. Meanwhile, July trend values for Gdynia, Warsaw, and Kraków for 1931$92,1901-98$, and $1901-99$ are $0.154,0,041$, and $0.007^{\circ} \mathrm{C} /$ decade, respectively. The values differ greatly from, and are much higher, than those for 1981-2010 for the entire area of Poland, because they amount to $0.81^{\circ} \mathrm{C} /$ decade.

For 1951-2005 [8], after averaging the results from 19 weather stations, for the months with the statistically significant trend of $\alpha=0.05$ for most weather stations, trend values can be estimated to be: 0.58 in February, 0.4 in March, 0.26 in April, 0.34 in May, 0.25 in August, and $0.19^{\circ} \mathrm{C} /$ decade for the whole year. When comparing these to the significant trend values from this study of 0.73 for April, 0.57 for June, 0.81 for July, and 0.48 for August, and $0.33^{\circ} \mathrm{C} /$ decade for the whole year, huge degrees of conformity are not noticeable. Above all, the value of the annual values trend for the longer period is understated in comparison with the values given in recent decades, and is estimated at $0.3^{\circ} \mathrm{C} /$ decade $[9,12]$.

Compared to the study for 1951-2010 [9], there is conformity only in April, July, and August, and trend values are twice as high as in the studies by the abovementioned authors. The annual trend value amounting to $0.22^{\circ} \mathrm{C} /$ decade is higher than the one for $1951-2005$ estimated on the basis of means from 19 weather stations at $19^{\circ} \mathrm{C} /$ decade, but far from the $0.33^{\circ} \mathrm{C} /$ decade resulting from research referring to 1981-2010.

In light of the strategic adaptation plan for sectors, and areas sensitive to climate change until 2070 [25], the pace of increase of annual mean air temperature value will amount to a little less than those forecasted in the decades to come. If we compare 2041-50 to 2001-10, the pace can be estimated to be $0.28^{\circ} \mathrm{C} /$ decade, and if we compare $2041-50$ to $2011-20$, the pace is $23^{\circ} \mathrm{C} /$ decade. A greater warming similar to the one claimed in the study $\left(0.32\right.$ and $0.31^{\circ} \mathrm{C} /$ decade, in relation to the abovementioned base periods) is expected toward the end of this century, in 2071-91. The greatest noticeable temperature increases in southeastern Poland in summer also will be noticeable in the further time perspective - above all in the perspective of the greatest increase of the number of hot days (with maximum temperature above $25^{\circ} \mathrm{C}$ ) indicated in the strategic adaptation plan for the 2041-71 period compared to the 1971-2000 base period [25]. In the near future (2021-50), a somewhat greater winter temperature increase of the order of $0.3^{\circ} \mathrm{C} /$ decade is to be expected, whereas the decadal increased in the study carried out can be estimated at $0.2^{\circ} \mathrm{C} /$ decade.

\section{Conclusions}

On the basis of the research carried out on air temperature trend analysis concerning annual mean values, and also values for the particular months for regional values for Poland, and concerning the spatial differentiation of the researched phenomenon in the 1981-2010 period, we can draw the following conclusions:

1. A faster increase in air temperature was stated in the 1981-2010 period, compared to the research based on data that included the beginning of the second half of the $20^{\text {th }}$ century.

2. The two last decades of the $20^{\text {th }}$ century and the first decade of the $21^{\text {st }}$ century are noteworthy because in those periods warming was visible not only in winter, but also in spring and summer.

3. The warming in Poland in the 1981-2010 period, amounting to $0.33^{\circ} \mathrm{C} /$ decade, resulted mainly from a spring and summer temperature increase of $\alpha=0.05$. The greatest pace of temperature increase are found in July (0.81) and April (0.73), slightly lower in June (0.57), and August $\left(0.48^{\circ} \mathrm{C} /\right.$ decade $)$.

4. The high trend for February $\left(0.85^{\circ} \mathrm{C} /\right.$ decade $)$ is not statistically significant. Trend values in October and December, of the order of $0.2^{\circ} \mathrm{C} /$ decade, are negative but statistically insignificant.

5. The greatest increases in air temperature in April are in Midwestern Poland, and in June in southwestern Poland. In July and August the greatest temperature trends are marked in eastern Poland.

6. The stated annual trends are of the order of values given in climate change scenarios for the $21^{\text {st }}$ century, for 2070-2100.

\section{References}

1. TRENBERTH K.E., JONES P.D., AMBENJE P., BOJARIU R., EASTERLING D., KLEIN TANK A., PARKER D., RAHIMZADEH F., RENWICK J.A., RUSTICUCCI M., SODEN B., ZHAI P. Observations: Surface and Atmospheric Climate Change. In: Climate change 2007: The Physical Science Basis. Contribution of Working Group I to the Fourth Assessment Report of the Intergovernmental Panel on Climate Change. SOLOMON S., QIN D., MANNING M., CHEN Z., MARQUIS M., AVERYT K.B., TIGNOR M., MILLER H.L. (eds.) Cambridge University Press. Cambridge, UK, New York, NY, USA, 2007.

2. JONES P.D., LISTER D.H., OSBORN T.J., HARPHAM C., SALMON M., MORICE C.P. Hemispheric and Large-Scale Land-Surface Air Temperature Variations: An Extensive Revision and an Update to 2010. J. Geophys. Res. Atmos. 117, 2012, D05127.

3. ROHDE, R., MULLER R.A., JACOBSEN R., MULLER E., PERLMUTTER S., ROSENFELD A., WURTELE J., GROOM D., WICKHAM C. A New Estimate of the Average Earth Surface Land Temperature Spanning 1753 to 2011. Geoinfor. Geostat.: An Overview 1, 2013, doi:10.4172/ gigs. 1000101 .

4. HANSEN J., RUEDY R., SATO M., LO K. Global Surface Temperature Change. Rev. Geophys. 48 (4), 1, 2010, RG4004.

5. LAWRIMORE J.H., MENNE M.J., GLEASON B.E., WILLIAMS C.N., WUERTZ D.B., VOSE R.S., RENNIE J. An Overview of the Global Historical Climatology Network Monthly Mean Temperature Data Set, version 3. J. Geophys. Res. Atmos. 116, 2011, D19121. 
6. JARRAUD M. WMO Report: The Global Climate 20012010: A Decade of Climate Extremes, July 6, 2013.

7. ŻMUDZKA E. Contemporary Changes of Climate of Poland. Acta Agrophysica 13 (2), 555-568, 2009 [In Polish].

8. MICHALSKA B. Tendencies of Air Temperature changes in Poland. Studies in Geography 47, 67-75, 2011 [In Polish].

9. WÓJCIK R., MIĘTUS M. Some Features of Long-Term Variability in Air Temperature in Poland (1951-2010). Polish Geographical Review 86, 3, 339-364, 2014 [In Polish].

10. KRUŻEL J. Ecological and Economic Consequences of Contemporary Changes of Thermal Features of the Climate of Poland (1971-2010). Master's thesis performed in Chair of Ecology, Climatology and Air Protection. Supervisor dr hab. inż. Agnieszka Ziernicka-Wojtaszek, 2014 [In Polish].

11. KOŻUCHOWSKI K., ŻMUDZKA E. Climate warming in Poland: the range and seasonality of the changes in air temperature in the second half of the $20^{\text {th }}$ century. Polish Geographical Review 46, 1-2, 81-90, 2001 [In Polish].

12. ŻMUDZKA E. Climatic background of the agricultural production in Poland in the second half of $20^{\text {th }}$ century. Acta Agrophysica 3 (2), 399, 2004 [In Polish].

13. LORENC H. Pluvio-thermal assessment of the climatic seasons of the year in Poland and their time and space tendencies. Research project 9, IMGW, synthetic report, 2000 [In Polish].

14. BORYCZKA J. Climate of the Earth: Past, Present, Future. Studies in Geography 29, UW, Warszawa, 55-72, 2001 [In Polish].

15. TREPIŃSKA J. The Air Temperature Fluctuations in Europe Since the Little Ice Age to the end $20^{\text {th }}$ Century. Studies in Geography 29, UW Warszawa, 73-76, 2001 [In Polish].

16. KOŻUCHOWSKI K. The Scale and Tendencies of the Contemporary Changes in Air Temperature in Poland. Lódź UŁ, 25-46, 2004 [In Polish].
17. MICHALSKA B. Variability of Air Temperature in North Western Poland (In.) Szwejkowski Z. (eds.) Environmental Aspects of Climate Change. UW-M, Olsztyn, 89-107, 2009 [In Polish].

18. ŻMUDZKA E. Changes in Thermal Conditions in the High Mountain Areas and Contemporary Warming in the Central Europe. Miscellanea Geographica 14, 59-70, 2010 [In Polish].

19. PIOTROWICZ K. The Differentiation of Thermal Seasons in Cracow. Geographical Studies UJ, 105, 111-124, 2000 [In Polish].

20. ŻARSKI J., KUŚNIEREK-TOMASZEWSKA R., DUDEK S. Trends of Variation in Thermal Agricultural Seasons in the Region of Bydgoszcz. Infrastructure and Ecology of Rural Areas 3/I, 7-17, 2012 [In Polish].

21. NIERÓBCA A., KOZYRA J., MIZAK K., WRÓBLEWSKA E. Changes in the Length of Growing Season in Poland. Water-Environment-Rural-Areas 13, 2, (42), 81, 2013 [In Polish].

22. ŻMUDZKA E., DOBROWOLSKA M. Variability of Thermal Vegetative Period in Poland in the Second Half of $20^{\text {th }}$ Century. Studies in Geography 29, 127-135, 2001 [In Polish].

23. ŻMUDZKA E. Long-term Changes of Thermal Resources in the Vegetative Period and the Active Growth of Plants in Polsce. Water-Environment-Rural-Areas 12, 2 (38), 377388, 2012 [In Polish].

24. OKONIEWSKA M. Changes of Air Temperature in Poland in XX Century on the Background of Air Circulation. Journal of Health Sciences 3 (15), 130-151, 2013 [In Polish].

25. SADOWSKI M. (eds.) Preparation and implementation of the Strategic Adaptation Plan for sectors and areas sensitive to climate changes until 2070 IOŚ-PIB Warszawa,, 2013 [In Polish]. 